\title{
Revisiting Species Distribution and Antifungal Susceptibility of Candida Bloodstream Isolates from Latin American Medical Centers
}

\author{
Daniel Archimedes da Matta, Ana Carolina Remondi Souza and Arnaldo Lopes Colombo * \\ Laboratório Especial de Micologia, Disciplina de Infectologia, Escola Paulista de Medicina, \\ Universidade Federal de São Paulo, São Paulo, SP 04039-032, Brazil; darchimedes@hotmail.com (D.A.d.M.); \\ carolina.remondi@yahoo.com.br (A.C.R.S.) \\ * Correspondence: arnaldolcolombo@gmail.com; Tel.: +55-11-5576-4985
}

Academic Editor: David S. Perlin

Received: 24 March 2017; Accepted: 12 May 2017; Published: 17 May 2017

\begin{abstract}
The epidemiology of candidemia varies geographically, and there is still scarce data on the epidemiology of candidemia in Latin America (LA). After extensive revision of medical literature, we found reliable and robust information on the microbiological aspects of candidemia in patients from 11 out of 21 medical centers from LA countries and 1 out of 20 from Caribbean countries/territories. Based on 40 papers attending our search strategy, we noted that $C$. albicans remains the most common species causing candidemia in our region, followed by C. parapsilosis and C. tropicalis. In Argentina, Brazil, and Colombia, a trend towards an increase in frequency of C. glabrata candidemia was observed. Although resistance rates to fluconazole is under 3\%, there was a slight increase in the resistance rates to C. albicans, C. parapsilosis and C. tropicalis isolates. Echinocandin resistance has been reported in a few surveys, but no single study confirmed the resistant phenotype reported by using molecular methods. We highlight the importance of conducting continuous surveillance studies to identify new trends in terms of species distribution of Candida and antifungal resistance related to episodes of candidemia in LA. This information is critical for helping clinicians to prevent and control Candida bloodstream infections in their medical centers.
\end{abstract}

Keywords: candidemia; Candida spp.; nosocomial infection; infections acquired in a healthcare setting; antifungal resistance; opportunistic infections

\section{Introduction}

Fungi has been increasingly recognized as major agents of nosocomial infections in contemporary medicine, with emphasis on Candida spp., that accounts for the majority of invasive fungal infections associated in healthcare facilities. Indeed, besides being highly prevalent in Latin America countries, candidemia is associated with high morbidity and mortality rates, especially in critically ill patients [1-7].

The epidemiology of candidemia varies geographically, and, although C. albicans is still considered the most common cause of candidemia, there is a concern with the increasing rates of invasive infections due to Candida non-albicans (CNA) species in different parts of the world [7-10]. The reasons for the differences in species distribution and for the emergence of CNA species are not fully understood. However, there seems to be an association with a combination of variables related to host underlying conditions and medical interventions, including different practices of antifungal prophylaxis and resources available for prevention of health care associated infections [5,9,11-17].

Recognition of the importance of Candida infections has led to a significant increase in the use of antifungal agents in regiments of prophylaxis and empirical therapy, resulting in the emergence 
of resistant clinical isolates, particularly against triazoles and echinocandins [18,19]. In this scenario, the recent emergence of fluconazole resistance among isolates that are usually primarily sensitive to this drug, including C. parapsilosis and C. tropicalis strains, is worth mentioning [8,20-24]. Regarding to echinocandins, though resistance is still considered uncommon, occurrence of isolates with lower susceptibility to this therapeutic class has been increasingly reported, particularly among C. glabrata isolates [19,25-27].

The awareness of local epidemiology and antifungal susceptibility profile of Candida infections in different medical centers has major relevance in terms of guiding clinicians in optimizing their strategy for prevention and treatment of such fungal infections. This review attempts to provide a better understanding of the landscape of species distribution and antifungal resistance rates among Candida bloodstream isolates obtained from patients admitted in Latin American and Caribbean medical centers.

\section{Methods}

Our search strategy for the literature review was based on extensive revision of publications listed at PubMed, Scientific Electronic Library Online (SciELO), and MEDLINE bibliographic databases along the period between 1997 and 2016, irrespective of language and country of publication. Papers were retrieved using the following key words: candidemia, fungemia, Candida bloodstream infection, invasive candidiasis, Candida species distribution, antifungal susceptibility, and antifungal resistance. For each of these subjects, we also narrowed our search by adding the continent and country including the following: Central America, Latin America, South America, Caribbean, Argentina, Bolivia, Brazil, Chile, Colombia, Costa Rica, Cuba, Dominican Republic, Haiti, Honduras, Jamaica, Mexico, Panama, Peru, Puerto Rico, Uruguay, and Venezuela. Papers were included in our analysis only if their methodology and results matched the following criteria: (i) Candida isolates were identified at species level by a reliable and accurate phenotypic or molecular method; (ii) availability of data related to at least 50 Candida bloodstream isolates sequentially collected from different patients admitted in tertiary hospitals along the period of study; (iii) information regarding antifungal susceptibility of Candida spp. generated by The European Committee on Antimicrobial Susceptibility Testing (EUCAST) or Clinical Laboratory Standard Institute (CLSI) microbroth methods. Rates of resistance to triazoles and echinocandins reflect the breakpoints available at the time when the study was published. Papers addressing identification and susceptibility tests of worldwide collections of Candida isolates were considered only if isolates were obtained from patients with candidemia and data from Latin American or Caribbean countries were addressed separately. For antifungal susceptibility results, we only considered studies that tested at least $60 \%$ of all original collections of Candida strains originally selected for the study.

\section{Results}

We identified 40 studies that contained our inclusion criteria providing data of species distribution and antifungal susceptibility of Candida strains related to episodes of candidemia documented in Latin American and Caribbean medical centers.

In terms of geographic origin, 22 papers were from Brazil, 4 from Argentina, 4 from Colombia, 2 from Mexico, and 1 each representing the following countries: Costa Rica, Peru, Venezuela, and Puerto Rico (Caribbean region). Of note, Puerto Rico is an unincorporated territory of the United States of America (USA), located in the Caribbean. In addition to 36 studies reporting data of single countries, we also evaluated results provided by 4 multicenter studies that tested Candida spp. bloodstream isolates from multiple Latin American countries including Argentina, Brazil, Chile, Colombia, Costa Rica, Ecuador, Honduras, Mexico, Peru, Uruguay, and Venezuela. In this scenario, we identified papers characterizing the etiologic pattern and antifungal susceptibility of episodes of candidemia documented in only 11 out of 21 Latin American countries and 1 out of 20 Caribbean countries and territories. Taking together all data available, we were able to characterize the species 
distribution in more than 12,000 episodes of Candida bloodstream infections documented in 40 medical centers from our region (Table 1, Figure 1, and Supplementary Materials). Among all Candida spp. isolates analysed for species distribution, only 5460 isolates had their antifungal susceptibility profile performed in 17 studies (Table 2).

Table 1. Species distribution of Candida bloodstream isolates from Latin American and Caribbean medical centers (1997-2016).

\begin{tabular}{|c|c|c|c|c|c|c|c|c|c|c|}
\hline \multirow{2}{*}{ Country/Territory } & \multirow{2}{*}{ Reference } & \multirow{2}{*}{ Period } & \multirow{2}{*}{$\begin{array}{c}\mathrm{n}^{\mathrm{e}} \\
\text { (No. of Centers) }\end{array}$} & \multicolumn{7}{|c|}{ Species Distribution (\%) } \\
\hline & & & & $C a^{\mathbf{a}}$ & $C p^{\mathrm{a}}$ & $C t^{\mathrm{a}}$ & Cgla $^{\mathrm{a}}$ & $C k^{\mathbf{a}}$ & C. $g u i^{\mathrm{a}}$ & OCS $^{b}$ \\
\hline Argentina & Rodero et al. (2005) [28 $]^{\mathrm{c}}$ & 1999-2000 & $253(36)$ & 42.5 & 29.9 & 16.5 & 2.7 & 1.18 & 0.39 & 6.83 \\
\hline Argentina & Cordoba et al. (2011) [29] ${ }^{c}$ & $2007-2008$ & $420(47)$ & 42.1 & 28.5 & 16.9 & 4.7 & 0.47 & 1.66 & 5.67 \\
\hline Argentina & Riera et al. (2014) [31] & $2010-2012$ & $158(4)$ & 41 & 20 & 12 & 10 & 1.5 & 3 & 12.5 \\
\hline Brazil & Colombo et al. (1999) [32] & $1995-1996$ & $145(6)$ & 37 & 25 & 24 & 4 & 1 & 2 & 7 \\
\hline Brazil & Costa et al. (2000) [33] ${ }^{\mathrm{c}}$ & 1994-1996 & $84(1)$ & 51.2 & 17.8 & 11.9 & 2.3 & 1.19 & 9.5 & 6.11 \\
\hline Brazil & Colombo et al. (2003) [34] & 1996-1998 & $200(5)$ & 41.5 & 20.5 & 24 & 4.5 & 1 & 2 & 6.5 \\
\hline Brazil & Aquino et al. (2005) [37] & 1998-2004 & $131(1)$ & 45 & 24.4 & 15.3 & 6.9 & 4.6 & 0.76 & 3.04 \\
\hline Brazil & Colombo et al. (2006) [38] & 2003-2004 & $712(11)$ & 40.9 & 20.5 & 20.9 & 4.9 & 1.1 & 2.4 & 9.3 \\
\hline Brazil & Medrano et al. (2006) [39] & 2000-2002 & $50(1)$ & 28 & 36 & 16 & 4 & 0 & 12 & 4 \\
\hline Brazil & Colombo et al. (2007) [40] & $2002-2003$ & $282(4)$ & 38 & 23 & 17 & 3 & 1 & 6 & 12 \\
\hline Brazil & da Matta et al. (2007) [41] & 1995-2003 & $1000(4)$ & 40 & 23.8 & 24.3 & 4.4 & 0.6 & 3 & 3.9 \\
\hline Brazil & Girao et al. (2008) [42] & 1999-2006 & $108(1)$ & 40 & 18 & 34 & 1 & 3 & 1 & 3 \\
\hline Brazil & Franca et al. (2008) [43] & 2001-2004 & $100(1)$ & 59 & 9 & 15 & 7 & 2 & 2 & 6 \\
\hline Brazil & Colombo et al. (2013) [15] & 2006-2007 & $300(9)$ & 34 & 26 & 24 & 7 & 3 & 2 & 4 \\
\hline Brazil & Santos et al. (2014) [49] & 1995-2009 & $422(1)$ & 35.7 & 46.6 & 9.7 & 3.5 & 0.94 & 1.65 & 1.91 \\
\hline Brazil & Colombo et al. (2014) [2] & 2003-2012 & $1392(22)$ & 42 & 19 & 20 & 9 & 1.14 & 0.86 & 8 \\
\hline Brazil & da Costa et al. (2014) [50] & 2006-2011 & $108(1)$ & 28.7 & 24.1 & 30.5 & 8.3 & 1.8 & 0 & 6.6 \\
\hline Brazil & Doi et al. (2016) [51] & 2007-2010 & $137(16)$ & 34.3 & 24.1 & 15.3 & 10.2 & 1.5 & 0.7 & 13.9 \\
\hline Colombia & Cortes et al. (2011) [52] ${ }^{\mathrm{c}}$ & 2001-2007 & $1622(27)$ & 50.9 & 15.5 & 15.5 & 2 & 2.36 & 3.3 & 10.44 \\
\hline Colombia & Cortes et al. (2013) [53] & 2004-2008 & $382(7)$ & 56 & 16 & 17.3 & 2.6 & 0.8 & 0 & 7.3 \\
\hline Colombia & Cortes et al. (2014) [54] & 2008-2009 & $131(7)$ & 66.4 & 14.5 & 10.6 & 1.5 & 0 & 1.5 & 5.5 \\
\hline Colombia & Ortiz Ruiz et al. (2016) [55] & 2008-2012 & $81(3)$ & 52 & 17 & 17 & 6 & 3 & 4 & 1 \\
\hline Costa Rica & Villalobos et al. (2016) [56] & $2007-2011$ & $210(1)$ & 38 & 42 & 10 & 7 & $N^{f}$ & NR & 3 \\
\hline Mexico & Gonzalez et al. (2008) [57] & 2004-2007 & $398(5)$ & 31.9 & 37.9 & 14.8 & 8 & 2.7 & 1.3 & 3.3 \\
\hline Mexico & Corzo-Leon et al. (2014) [58] & 2008-2010 & $74(2)$ & 46 & 5 & 26 & 13.5 & 5 & 3 & 1.5 \\
\hline Peru & Bustamante et al. (2014) [59] & 2009-2011 & $153(1)$ & 39.9 & 28.1 & 23.5 & 5.2 & 0.7 & 2 & 0.6 \\
\hline Puerto Rico & Conde-Rosa et al. (2010) [60] & 2005-2006 & $85(1)$ & 28 & 49 & 17 & 4 & 1 & 0 & 1 \\
\hline
\end{tabular}

${ }^{a}$ Ca: C. albicans. Cp: C. parapsilosis (sensu lato). Ct: C. tropicalis. Cgla: C. glabrata. Ck: C. krusei. Cgui: C. guilliermondii (sensu lato); ${ }^{b}$ Other Candida Species-species other than C. albicans. C. parapsilosis (sensu lato). C. tropicalis. C. glabrata. C. krusei. C. guilliermondii (sensu lato); ${ }^{\mathrm{c}}$ Fungemia collection. Percentage of species distribution was recalculated taking in account only Candida species as denominator; ${ }^{\mathrm{d}}$ Multicenter studies including different countries in Latin America; ${ }^{e}$ Number of Candida isolates; and ${ }^{\mathrm{f}}$ NR: Not Reported.

C. albicans, C. parapsilosis (sensu lato), C. tropicalis, and C. glabrata were the most commonly found species causing candidemia in all countries. C. albicans was the main cause of candidemia in 32 out of 40 studies exhibiting prevalence rates ranging between $18.8 \%$ and $66 \%$. The highest prevalence rate of C. albicans candidemia was reported by Cortes et al. (2014) in Colombia [54]. It is worth to mention that all 4 studies from Colombia had C. albicans prevalence rates higher than $50 \%$. In contrast, less than $30 \%$ of prevalence rates of C. albicans strains were reported in Brazil by Medrano et al. (2006) and da Costa et al. (2014), by Conde-Rosa et al. (2010) in a single study reported in Puerto Rico, and by Franco et al. (2008) in Venezuela [39,50,60,61]. In these studies, C. tropicalis and/or C. parapsilosis were the most commonly found species causing candidemia.

C. parapsilosis (sensu lato) isolates ranged from $5 \%$ to $49 \%$ of all candidemic episodes. Indeed, C. parapsilosis was identified as the main agent of CNA species candidemia in 25 out of 40 studies, and in 6 of the studies it surpassed the prevalence rate of $C$. albicans. 
Table 2. Azole resistance rates of C. albicans, C. parapsilosis (sensu lato) and C. tropicalis bloodstream isolates from Latin American medical centers (1997-2016).

\begin{tabular}{|c|c|c|c|c|c|c|c|}
\hline \multirow{2}{*}{ Country } & \multirow{2}{*}{ Reference; Number of Isolates } & \multirow{2}{*}{ Method } & \multirow{2}{*}{ Species } & \multicolumn{2}{|c|}{ Fluconazole } & \multicolumn{2}{|c|}{ Voriconazole } \\
\hline & & & & SDD $^{a}$ & $\mathbf{R}^{\mathbf{b}}$ & SDD & $\mathbf{R}$ \\
\hline \multirow{3}{*}{ Argentina } & \multirow{3}{*}{$\begin{array}{l}\text { Rodero et al. (2006) [28]; } \\
\qquad n=265\end{array}$} & \multirow{3}{*}{$\begin{array}{l}\mathrm{CLSI}^{\mathrm{c}} \times \\
(\mathrm{EUCAST})\end{array}$} & $\mathrm{Ca}{ }^{\mathrm{e}}$ & $N R^{i}$ & $15.7 \%(1.8 \%)$ & $\mathrm{NT}^{\mathrm{j}}$ & NT \\
\hline & & & $C p^{f}$ & NR & $0 \%(0 \%)$ & NT & NT \\
\hline & & & $C t \mathrm{~g}$ & NR & $43 \%(5.4 \%)$ & NT & NT \\
\hline \multirow{3}{*}{ Argentina } & \multirow{3}{*}{$\begin{array}{c}\text { Cordoba et al. (2011) [29]; } \\
\quad n=420\end{array}$} & \multirow[t]{3}{*}{ EUCAST $^{\mathrm{d}}$} & $\mathrm{Ca}$ & NR & $0 \%$ & NR & $0.5 \%$ \\
\hline & & & $\mathrm{Cp}$ & NR & $2.5 \%$ & NR & $0.8 \%$ \\
\hline & & & $C t$ & NR & $4.2 \%$ & NR & $4.2 \%$ \\
\hline \multirow{3}{*}{ Brazil } & \multirow{3}{*}{$\begin{array}{l}\text { Colombo et al. (2003) [34]; } \\
\qquad n=200\end{array}$} & \multirow[t]{3}{*}{ CLSI } & $\mathrm{Ca}$ & $1.2 \%$ & $0 \%$ & NT & NT \\
\hline & & & $C p$ & $0 \%$ & $0 \%$ & NT & NT \\
\hline & & & $C t$ & $0 \%$ & $0 \%$ & NT & NT \\
\hline \multirow{3}{*}{ Brazil } & \multirow{3}{*}{$\begin{array}{l}\text { Antunes et al. (2004) [36]; } \\
\qquad n=120\end{array}$} & \multirow[t]{3}{*}{ CLSI } & $\mathrm{Ca}$ & $0 \%$ & $0 \%$ & NT & NT \\
\hline & & & $C p$ & $0 \%$ & $0 \%$ & NT & NT \\
\hline & & & $C t$ & $0 \%$ & $0 \%$ & NT & NT \\
\hline \multirow{3}{*}{ Brazil } & Aquino et al. (2005) [37]; & CLSI & $\mathrm{Ca}$ & $0 \%$ & $0 \%$ & NT & NT \\
\hline & $n=131$ & & $C p$ & $0 \%$ & $0 \%$ & NT & NT \\
\hline & & & $C t$ & $0 \%$ & $0 \%$ & NT & NT \\
\hline & Colombo et al. (2006) [38]; & CLSI & $\mathrm{Ca}$ & $0.3 \%$ & $0.3 \%$ & $0 \%$ & $0.3 \%$ \\
\hline Brazil & $n=712$ & & $\mathrm{Cp}$ & $0 \%$ & $0 \%$ & $0 \%$ & $0 \%$ \\
\hline & & & $C t$ & $1.3 \%$ & $0 \%$ & $0 \%$ & $0 \%$ \\
\hline & Colombo et al. (2007) [40]; & CLSI & $\mathrm{Ca}$ & $0 \%$ & $0 \%$ & NT & NT \\
\hline Brazil & $n=282$ & & $\mathrm{Cp}$ & $0 \%$ & $0 \%$ & NT & NT \\
\hline & & & $C t$ & $0 \%$ & $0 \%$ & NT & NT \\
\hline & da Matta et al. (2007) [41]; & CLSI & $\mathrm{Ca}$ & $0 \%$ & $0 \%$ & $0 \%$ & $0 \%$ \\
\hline Brazil & $n=1000$ & & $C p$ & $0 \%$ & $0 \%$ & $0 \%$ & $0 \%$ \\
\hline & & & $\mathrm{Ct}$ & $0 \%$ & $0 \%$ & $0 \%$ & $0 \%$ \\
\hline & Bonfietti et al. (2012) [46]; & EUCAST & $\mathrm{Ca}$ & $0 \%$ & $0 \%$ & $0 \%$ & $0 \%$ \\
\hline Brazil & $n=100$ & & $C p$ & $6 \%$ & $0 \%$ & $0 \%$ & $3 \%$ \\
\hline & & & $C t$ & $0 \%$ & $0 \%$ & $0 \%$ & $0 \%$ \\
\hline & Colombo et al. (2013) [15]; & CLSI & $\mathrm{Ca}$ & $0 \%$ & $0 \%$ & $0 \%$ & $0 \%$ \\
\hline Brazil & $n=300$ & & $C p$ & $1.3 \%$ & $0 \%$ & $0 \%$ & $0 \%$ \\
\hline & & & $C t$ & $2.5 \%$ & $0 \%$ & $0 \%$ & $0 \%$ \\
\hline & Santos et al. (2014) [49]; & CLSI & $\mathrm{Ca}$ & $9.9 \%$ & $0 \%$ & $2.6 \%$ & $0 \%$ \\
\hline Brazil & $n=422$ & & $C p$ & $7 \%$ & $0 \%$ & $3.5 \%$ & $0 \%$ \\
\hline & & & $C t$ & $19.5 \%$ & $7.3 \%$ & $12 \%$ & $4.9 \%$ \\
\hline & da Costa et al. (2014) [50]; & EUCAST & $\mathrm{Ca}$ & NR & $3.7 \%$ & NR & $3.7 \%$ \\
\hline Brazil & $n=108$ & & $C p$ & NR & $26.9 \%$ & NR & $0 \%$ \\
\hline & & & $C t$ & NR & $3,2 \%$ & NR & $3.2 \%$ \\
\hline & Gonzalez et al. (2014) [57]; & CLSI & $\mathrm{Ca}$ & $0 \%$ & $0.8 \%$ & $0 \%$ & 0.8 \\
\hline Mexico & $n=398$ & & $C p$ & $0 \%$ & $0 \%$ & $0 \%$ & $0 \%$ \\
\hline & & & $C t$ & $0 \%$ & $0 \%$ & $0 \%$ & $0 \%$ \\
\hline & Corzo-Leon et al. (2014) [58]; & CLSI & $\mathrm{Ca}$ & $0 \%$ & $0 \%$ & $0 \%$ & $0 \%$ \\
\hline Mexico & $n=74$ & & $\mathrm{Cp}$ & $0 \%$ & $0 \%$ & $0 \%$ & $0 \%$ \\
\hline & & & $C t$ & $0 \%$ & $0 \%$ & $0 \%$ & $0 \%$ \\
\hline & Bustamante et al. (2014) [59]; & CLSI & $\mathrm{Ca}$ & NR & NR & $0 \%$ & $5 \%$ \\
\hline Peru & $n=153$ & & $C p$ & NR & $2.3 \%$ & NR & NR \\
\hline & & & $C t$ & NR & NR & NR & NR \\
\hline Multicenter & Godoy et al. (2003) [64]; & CLSI & $\mathrm{Ca}$ & $0 \%$ & $0 \%$ & NT & NT \\
\hline studies $\mathrm{h}$ & $n=103$ & & $C p$ & $0 \%$ & $0 \%$ & NT & NT \\
\hline & & & $C t$ & $0 \%$ & $0 \%$ & NT & NT \\
\hline Multicenter & Nucci et al. (2013) [7]; & CLSI & $\mathrm{Ca}$ & $0,4 \%$ & $0 \%$ & $0 \%$ & $0 \%$ \\
\hline studies & $n=672$ & & $C p$ & $1,1 \%$ & $0 \%$ & $0 \%$ & $0 \%$ \\
\hline & & & $C t$ & $0 \%$ & $0 \%$ & $0 \%$ & $0 \%$ \\
\hline
\end{tabular}

${ }^{a}$ Susceptible in a dose-dependent manner; ${ }^{b}$ Resistant to azoles; ${ }^{c}$ Clinical Laboratory Standard Institute; ${ }^{\mathrm{d}}$ European Committee on Antimicrobial Susceptibility Testing; e C. albicans; ${ }^{\mathrm{f}}$ C. parapsilosis (sensu lato); $\mathrm{g}$ C. tropicalis;

${ }^{\mathrm{h}}$ Multicenter studies including different countries from Latin America; ${ }^{\mathrm{i}}$ NR: Not reported; ${ }^{j} \mathrm{NT}$ : Not tested. 


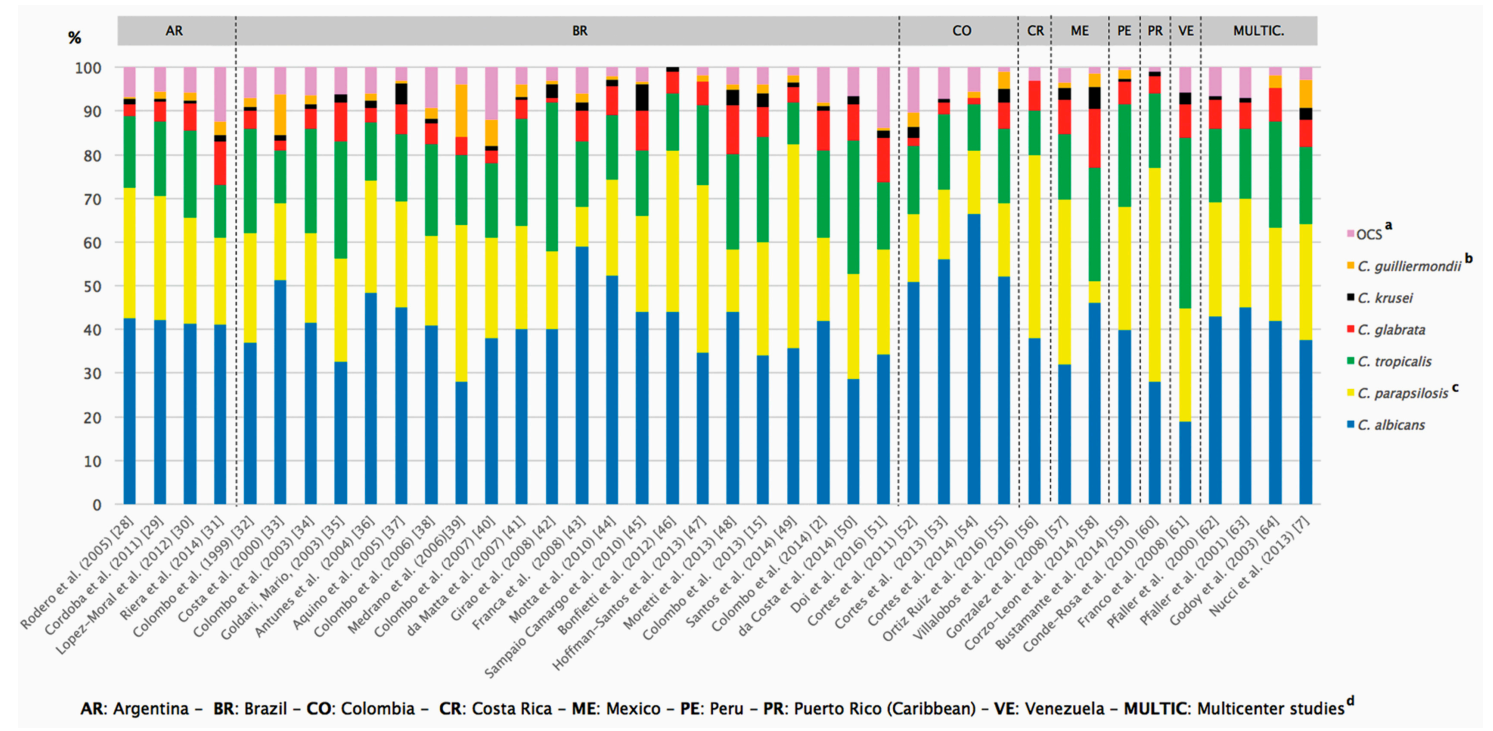

Figure 1. Proportion of the most common Candida species isolated from episodes of candidemia in Latin American and Caribbean medical centers (1997-2016). ${ }^{a}$ Other Candida Species-species other than C. albicans. C. parapsilosis (sensu lato). C. tropicalis. C. glabrata. C. krusei. C. guilliermondii (sensu lato); ${ }^{\mathrm{b}}$ C. guilliermondii (sensu lato); ${ }^{\mathrm{c}}$ C. parapsilosis (sensu lato); ${ }^{\mathrm{d}}$ Multicenter studies including different countries from Latin America.

C. tropicalis was the second most common CNA species isolated in our region exhibiting prevalence rates ranging between $9.7 \%$ and $39 \%$. Of note, C. tropicalis was the main cause of CNA species candidemia in 13 out of 40 studies. Franco et al. (2008) and da Costa et al. (2014) reported that C. tropicalis surpassed C. albicans in their surveys of candidemia [50,61]. In 2 casuistics conducted by Cortes et al. (2011) and Ortiz Ruiz et al. (2016), C. parapsilosis (sensu lato) and C. tropicalis infected exactly the same percentage of patients $[52,55]$.

Prevalence rates of $C$. glabrata presented a large variation among studies documented in different countries. In general, C. glabrata represented the third or fourth most common CNA species documented in Candida bloodstream infections, exhibiting prevalence rates ranging from $1 \%$ to $13.5 \%$. The highest rate for this species was found by Corzo-Leon et al. (2014) in Mexico where C. glabrata was considered the second most common cause of CNA candidemia behind only C. tropicalis [58].

Prevalence rates of $C$. krusei strains ranged from 0 to $6 \%$ among all studies. C. guilliermondii (sensu lato) was isolated in 33 out 40 studies, being reported in almost all countries represented in this review. The prevalence of $C$. guilliemondii candidemia ranged from 0 to $12 \%$. The highest prevalence rate of C. guilliermondii candidemia was found in Honduras, as reported by Nucci et al. (2013), along with the characterization of 672 episodes of candidemia carried out in Latin America [7].

All species other than C. albicans, C. parapsilosis (sensu lato), C. tropicalis, C. glabrata, C. krusei, and C. guilliermondii (sensu lato) were classified as other Candida species (OCSs). The highest rate of OCSs among the studies retrieved was observed by Doi et al. (2016) in Brazil with $13.9 \%$ of its collection [51]. Overall, the most common species documented, in at least 5 out of 40 studies, were C. rugosa, C. pelliculosa, C. lusitaniae, C. famata, C. lipolytica, and C. kefyr. The OCSs less frequently isolated were C. haemulonii, C. intermedia, C. sake, C. holmii, C. zeylanoides, C. utilis, C. viswanathii, C. dubliniensis, and C. novergensis.

Overall, we were able to identify historical trends in species distribution of Candida spp. only related to prevalence of C. glabrata. In this regard, as illustrated on Table 1, only 1 out of 8 Brazilian studies published between 1997 and 2006 presented prevalence rates of C. glabrata candidemia $\geq 7 \%$. Otherwise, 7 out of 14 studies published between 2007 and 2016 exhibited prevalence rates $\geq 7 \%$. Similarly, in Argentina there was a substantially increment of $C$. glabrata rates moving from a rate of 
$2.7 \%$ in the first study reported in 2005 to $10 \%$ in a recent casuistic involving 158 episodes of candidemia reported by Riera et al. (2014) [31]. In Colombia, prevalence rates of C. glabrata in candidemia remained lower than $3 \%$ along the first 3 studies, as illustrated on Figure 1, moving up to $6 \%$ in a recent study involving 81 episodes of fungemia.

It is seems that there was a slight increase in the prevalence rate of C. krusei candidemia in Brazil. Indeed, 7 out of 8 studies from Brazil exhibited prevalence rates of C. krusei $\leq 2 \%$ between 1997 and $2006[32,33,35,36,38,39,64]$. In contrast, 5 out of 14 studies published between 2007 and 2016 exhibited isolation rates $\geq 2 \%$ for this particular species $[15,42,43,45,48]$. Prevalence rates of $C$. krusei candidemia remained stable along different studies reported in Argentina and Colombia (see Table 1).

\section{Temporal Trends of Antifungal Resistance to Azoles and Echinocandins}

An overall review of the 40 studies retrieved for Candida species distribution analysis, only 17 of them presented reliable information on the antifungal susceptibility tests of strains using broth microdilution methods standardized by CLSI and EUCAST. In order to check for trends in terms of rising antifungal resistance along the study period, we compared data from 7 studies published between 1997 and 2006 to data generated from 10 studies published between 2007 and 2016 (Table 2).

Ten out of the 17 studies providing data on Candida antifungal resistance were performed in Brazilian medical centers, 2 were from Argentina, 2 from Mexico, and 1 from Peru. We included an analysis of data generated by two multicenter studies that provided additional information from Argentina, Brazil, Chile, Colombia, Ecuador, Honduras, Peru, and Venezuela.

Reviewing the antifungal drugs that were evaluated along the 17 studies, we found that only fluconazole was tested in all them, followed by amphotericin B in 15 studies. Other drugs frequently tested included voriconazole (11 studies), caspofungin (5 studies), and anidulafungin (4 studies). Data on micafungin was only reported in one study.

It is important to mention that no single author from the Latin American surveys reporting rates of antifungal resistance of Candida bloodstream isolates, either to triazoles or echinocandins, attempted to confirm their in vitro profile by checking the expression of molecular mechanisms of antifungal resistance.

(i) Trends in resistance to fluconazole and voriconazole among C. albicans, C. tropicalis, and C. parapsilosis isolates.

Resistance to azoles among isolates of $C$. albicans, C. tropicalis, and C. parapsilosis remained relatively unchanged over time. Except for one single study conducted by Rodero et al. (2005) in Argentina, all studies carried out prior to 2006 showed that less than 1\% of isolates exhibited a non-susceptible (susceptible in a dose dependent manner [SDD] or resistant) phenotype to fluconazole and voriconazole. Regarding the Argentinean casuistic, the authors reported fluconazole resistance rates of $15.7 \%$ and $1.8 \%$ for C. albicans, and $43 \%$ and $5.4 \%$ for C. tropicalis, by using CLSI and EUCAST, respectively [28].

After 2007, a slight increase in the percentage of resistance to fluconazole was noted. Overall, resistance rates to fluconazole increased from $0.4 \%$ to $1.2 \%$ among C. albicans, from $0.5 \%$ to $2.3 \%$ among isolates of $C$. tropicalis, and from 0 to $2.6 \%$ for $C$. parapsilosis $[7,15,29,46,49,50,57,59]$. For voriconazole, resistance rates remained around $1 \%$.

(ii) Trends in resistance to echinocandins among Candida spp.

Only 7 out of 17 studies, all published after 2007, have provided data on antifungal susceptibility of at least one of the 3 echinocandins available for clinical use in Latin America. Of note, echinocandin resistance was reported in only 3 out of 7 mentioned studies. In Brazil, Santos et al. (2014) reported that 3 out of $15(20 \%)$ of $C$. glabrata isolates were non-susceptible to caspofungin [49]. Similar data were observed by Bustamante et al. (2014) in Peru where 1 out of 8 (12.5\%) of C. glabrata strains was resistant to anidulanfungin [59]. The only study reporting in vitro echinocandin resistance against species other 
than C. glabrata was conducted by Cordoba et al. (2011) in Argentina where they found 26 out of $120(21.6 \%)$ of C. parapsilosis isolates resistant to anidulafungin by using the EUCAST microdilution method [29].

\section{Discussion}

Candidemia remains a significant public health problem worldwide [1-7]. In Latin America, the incidence rates range from 0.74 to 6.0 per 1000 hospital admissions [30,38,45,48,56,58]. Despite all advances related to the development of new diagnostic and therapeutic tools for fungal infections, crude mortality rates of candidemia remain high in Latin American medical centers, ranging from 30 to $76 \%[28,42,44,51,55,56,58,60]$.

As expected, C. albicans remains the most common species causing candidemia in our region, followed by C. parapsilosis and C. tropicalis $[65,66]$. Otherwise, prevalence rates of C. glabrata were highly variable within different studies and different countries. The same variation observed among several countries was noted in one recent global trend review of Candida species distribution, where prevalence rates of $C$. glabrata in candidemic patients in European medical centers ranged between 8\% (Spain) and 20\% (Denmark) [10]. In Brazil, Argentina and Colombia, we noted a trend towards an increase in C. glabrata frequency $[28,31,41,48]$ along the period of study. This increase has an important clinical impact, as C. glabrata shows a diminished susceptibility to azoles and, eventually, candins [27]. Although the explanation for this shift is not completely understood, it seems to be a consequence of the increased exposure to fluconazole, as previously demonstrated by several authors $[5,13]$.

C. krusei and C. guilliermondii (sensu lato) frequencies have not demonstrated substantial changes in their frequency, but both species were found in most studies from different countries. In fact, C. krusei was found in 36 out of 40 articles, while C. guilliermondii (sensu lato) was found in 33. Of note, in the single multicenter study conducted by Nucci et al. (2013) in 7 countries, C. guilliermondii ranged from $1.6 \%$ to $20 \%$ [7]. Due to their reduced susceptibility to fluconazole, both C. krusei and C. guilliermondii may have a relevant clinical impact in terms of defining strategy for empirical therapy of risk patients $[67,68]$.

One limitation found in all studies reviewed is that only phenotypic methods were used to identify Candida species involved in the episodes of candidemia. Consequently, accurate identification of cryptic species of Candida could not be provided. In addition, we may not exclude the possibility that the OCSs reported by the authors, including C. rugosa, C. pelliculosa, C. lusitaniae, C. famata, C. lipolytica, and C. kefyr, were misidentified by inaccurate phenotypic methods used by the routine laboratories. There is a consensus that MALDI-TOF and sequencing of the Internal Transcribed Spacer (ITS) region of ribosomal DNA are both considered to be far more accurate and reliable for providing identification of cryptic and rare species of Candida than conventional methods [69-71].

In this regard, despite the fact that $C$. auris strains have not been detected as OCSs causing infection along the 40 mentioned surveys of candidemia performed in our region, two recent reports documented outbreaks of $C$. auris candidemia in medical centers from Venezuela and Colombia [72,73]. This microorganism has been recognized as a multidrug-resistant yeast pathogen since all C. auris strains are fully resistant to fluconazole and part of them may be either resistant to candins and/or amphotericin B. We may not exclude the possibility that the real prevalence of this emerging multidrug-resistant yeast pathogen is underestimated in our region since it has been misidentified in routine laboratories as C. famata and C. haemulonii, among others [74].

Fluconazole resistance has been increasingly noted in Candida spp., not only with C. glabrata but also among strains initially described as primarily sensitive to azoles such as C. parapsilosis and C. tropicalis $[8,10,20-22,24,75-77]$. In the review presented, we decided not to focus our analysis on fluconazole resistance against $C$. glabrata strains since fluconazole is not considered a safe alternative anymore for treating candidemic patients infected by this pathogen $[67,68]$.

Several studies have reported variations in fluconazole resistance rates among C. parapsilosis and C. tropicalis isolates. Indeed, resistance rates among C. parapsilosis isolates ranged from $3.4 \%$ to $7.5 \%$ in 
USA and from 0 to $6 \%$ in Europe [8,20-22,75-78]. For C. tropicalis, resistance rates ranged from $2.4 \%$ to $11.6 \%$ in USA and from $1.7 \%$ to $22 \%$ in Europe [8,20-22,75-78]. In Latin America, we have noted a slight increase in C. albicans, C. parapsilosis, and C. tropicalis isolates exhibiting a non-susceptible profile to fluconazole along our study period. Indeed, resistance rates to fluconazole increased from $0.4 \%$ to $1.2 \%$ among $C$. albicans isolates; from $0.5 \%$ to $2.3 \%$ among isolates of $C$. tropicalis and from 0 to $2.6 \%$ for C. parapsilosis strains. Of note, though still considered rare, a recent publication from Brazil described an outbreak of C. parapsilosis (sensu stricto) candidemia involving 23 intensive care unit (ICU) patients from a single institution [24]. Resistance to fluconazole in C. parapsilosis strains in this particular report was confirmed by the presence of ERG11 mutations and overexpression of efflux pumps by the mentioned strains [79].

Resistance to echinocandins has been described as an uncommon phenomenon among C. albicans, C. parapsilosis, C. tropicalis, and C. krusei isolates [80]. However, it has become increasingly common among C. glabrata strains from patients admitted in US and European hospitals [27,80-82]. In Latin America, apparently, echinocandin resistance remains rare. It is important to mention that echinocandins are rarely used for the treatment of candidemic patients in Latin America in spite of the drug's availability in the early 2000s.

According to Nucci et al. (2013), only 40 (5.9\%) out of 672 patients with candidemia documented between 2008 and 2010 were initially treated with echinocandins [7]. Another aspect to consider is that antifungal resistance in Latin America may be underestimated since most routine laboratories do not perform antifungal susceptibility tests.

In our analysis, only 3 out of 40 studies documented any rate of echinocandin resistance with Candida sp. bloodstream isolates. Santos et al. (2014) and Bustamante et al. (2014) reported resistance rates of $20 \%$ and $12.5 \%$ to echinocandins among C. glabrata isolates, respectively [49,59]. Cordoba et al. (2011) reported that $21.6 \%$ of $C$. parapsilosis isolates were resistant to anidulafungin [29]. However, the high rates of resistance reported by these papers should be interpreted very carefully since they have not confirmed the echinocandin resistance phenotype by checking the presence of fks mutations in all isolates exhibiting high values of minimum inhibitory concentration (MIC) for echinocandins.

Currently, only two reports from medical centers in Latin America have demonstrated microbiological and molecular echinocandin resistance against Candida bloodstream isolates. Bizerra et al. (2014), using sequencing methodology for the study of $F K S$ genes and quantification of glucan synthesis, reported the occurrence of a mutation associated with the resistance phenotype against echinocandins in C. glabrata isolated from a single cancer patient with candidemia exposed to antifungal prophylaxis with micafungin [25]. Finally, Forastiero et al. (2015) reported a rapid development of resistance in C. krusei isolates recovered from a patient under caspofungin treatment. Clinical resistance was associated with increased echinocandin MICs and was ultimately related to new mutations of the target enzyme (fks1) [83].

\section{Conclusions}

In conclusion, there has been a changing epidemiology of Candida bloodstream infection over the past years in Latin America. Although C. albicans remains the predominant cause of candidemia, a shift has been reported in the epidemiology as some CNA species have emerged as the cause of candidemia, and they can exhibit resistance to fluconazole and echinocandins. Several medical centers have reported episodes of candidemia due to C. tropicalis and C. parapsilosis isolates resistant to fluconazole. Echinocandin resistance confirmed by molecular studies has been reported in only two episodes of candidemia reported in patients assisted at medical centers from Latin America, and appears to be rare in our region. Continuous multicenter surveillance studies of candidemia in Latin America are necessary to detect any regional and historical trends, in terms of Candida species distribution and emergence of antifungal resistance, early. This information is critical to clinicians in preventing and controlling Candida bloodstream infections in our medical centers. 
Supplementary Materials: The following are available online at www.mdpi.com/2309-608X/3/2/24/s1.

Acknowledgments: We thank Mary Nagel, QMS consultant (USA) from Laboratoire Nacional de Santé Publique in Haiti, for reviewing this manuscript. Daniel Archimedes da Matta and Ana Carolina Remondi Souza received a post-doc scholarship from Comissão de Aperfeiçoamento de Pessoal do Nível Superior (CAPES) in the Programa Nacional de Pós Doutorado (PNPD Program), Brazil. Arnaldo Lopes Colombo received grants from Conselho Nacional de Desenvolvimento Científico e Tecnológico, Brazil, (CNPq, Grant 307510/2015-8).

Author Contributions: Daniel Archimedes da Matta reviewed the literature, retrieved the articles and was responsible to analyse and write about Candida species distribution. Ana Carolina Remondi Souza wrote the topic antifungal resistance and formatted the manuscript according to Journal of Fungi. Arnaldo Lopes Colombo designed the study strategy, wrote part of the discussion and reviewed the whole manuscript.

Conflicts of Interest: Arnaldo Lopes Colombo has received educational grants from Astellas, Gilead, Pfizer, and United Medical and research grants from Astellas and Pfizer. All other authors: none to declare.

\section{References}

1. Magill, S.S.; Edwards, J.R.; Bamberg, W.; Beldavs, Z.G.; Dumyati, G.; Kainer, M.A.; Lynfield, R.; Maloney, M.; McAllister-Hollod, L.; Nadle, J.; et al. Multistate point-prevalence survey of health care-associated infections. N. Engl. J. Med. 2014, 370, 1198-1208. [CrossRef] [PubMed]

2. Colombo, A.L.; Guimaraes, T.; Sukienik, T.; Pasqualotto, A.C.; Andreotti, R.; Queiroz-Telles, F.; Nouer, S.A.; Nucci, M. Prognostic factors and historical trends in the epidemiology of candidemia in critically ill patients: An analysis of five multicenter studies sequentially conducted over a 9-year period. Intensive Care Med. 2014, 40, 1489-1498. [CrossRef] [PubMed]

3. Delaloye, J.; Calandra, T. Invasive candidiasis as a cause of sepsis in the critically ill patient. Virulence 2014, 5, 161-169. [CrossRef] [PubMed]

4. Bassetti, M.; Righi, E.; Ansaldi, F.; Merelli, M.; Trucchi, C.; De Pascale, G.; Diaz-Martin, A.; Luzzati, R.; Rosin, C.; Lagunes, L.; et al. A multicenter study of septic shock due to candidemia: Outcomes and predictors of mortality. Intensive Care Med. 2014, 40, 839-845. [CrossRef] [PubMed]

5. Lortholary, O.; Renaudat, C.; Sitbon, K.; Madec, Y.; Denoeud-Ndam, L.; Wolff, M.; Fontanet, A.; Bretagne, S.; Dromer, F.; French Mycosis Study, G. Worrisome trends in incidence and mortality of candidemia in intensive care units (Paris Area, 2002-2010). Intensive Care Med. 2014, 40, 1303-1312. [CrossRef] [PubMed]

6. Tedeschi, S.; Tumietto, F.; Giannella, M.; Bartoletti, M.; Cristini, F.; Cioni, G.; Ambretti, S.; Carretto, E.; Sambri, V.; Sarti, M.; et al. Epidemiology and outcome of candidemia in internal medicine wards: A regional study in italy. Eur. J. Intern. Med. 2016, 34, 39-44. [CrossRef] [PubMed]

7. Nucci, M.; Queiroz-Telles, F.; Alvarado-Matute, T.; Tiraboschi, I.N.; Cortes, J.; Zurita, J.; Guzman-Blanco, M.; Santolaya, M.E.; Thompson, L.; Sifuentes-Osornio, J.; et al. Epidemiology of candidemia in Latin America: A laboratory-based survey. PLoS ONE 2013, 8, e59373. [CrossRef] [PubMed]

8. Pfaller, M.A.; Jones, R.N.; Castanheira, M. Regional data analysis of candida non-albicans strains collected in united states medical sites over a 6-year period, 2006-2011. Mycoses 2014, 57, 602-611. [CrossRef] [PubMed]

9. Pfaller, M.A.; Andes, D.R.; Diekema, D.J.; Horn, D.L.; Reboli, A.C.; Rotstein, C.; Franks, B.; Azie, N.E. Epidemiology and outcomes of invasive candidiasis due to non-albicans species of candida in 2,496 patients: Data from the prospective antifungal therapy (path) registry 2004-2008. PLoS ONE 2014, 9, e101510. [CrossRef] [PubMed]

10. Guinea, J. Global trends in the distribution of candida species causing candidemia. Clin. Microbiol. Infect. 2014, 20, 5-10. [CrossRef] [PubMed]

11. Ruggero, M.A.; Topal, J.E. Development of echinocandin-resistant candida albicans candidemia following brief prophylactic exposure to micafungin therapy. Transpl. Infect. Dis 2014, 16, 469-472. [CrossRef] [PubMed]

12. Cuervo, G.; Garcia-Vidal, C.; Nucci, M.; Puchades, F.; Fernandez-Ruiz, M.; Obed, M.; Manzur, A.; Gudiol, C.; Peman, J.; Aguado, J.M.; et al. Breakthrough candidaemia in the era of broad-spectrum antifungal therapies. Clin. Microbiol. Infect. 2016, 22, 181-188. [CrossRef] [PubMed]

13. Ben-Ami, R.; Olshtain-Pops, K.; Krieger, M.; Oren, I.; Bishara, J.; Dan, M.; Wiener-Well, Y.; Weinberger, M.; Zimhony, O.; Chowers, M.; et al. Antibiotic exposure as a risk factor for fluconazole-resistant Candida bloodstream infection. Antimicrob. Agents Chemother. 2012, 56, 2518-2523. [CrossRef] [PubMed]

14. Mikulska, M.; Del Bono, V.; Ratto, S.; Viscoli, C. Occurrence, presentation and treatment of candidemia. Expert Rev. Clin. Immunol. 2012, 8, 755-765. [CrossRef] [PubMed] 
15. Colombo, A.L.; Garnica, M.; Aranha Camargo, L.F.; Da Cunha, C.A.; Bandeira, A.C.; Borghi, D.; Campos, T.; Senna, A.L.; Valias Didier, M.E.; Dias, V.C.; et al. Candida glabrata: An emerging pathogen in Brazilian tertiary care hospitals. Med. Mycol. 2013, 51, 38-44. [CrossRef] [PubMed]

16. Yang, Z.T.; Wu, L.; Liu, X.Y.; Zhou, M.; Li, J.; Wu, J.Y.; Cai, Y.; Mao, E.Q.; Chen, E.Z.; Lortholary, O. Epidemiology, species distribution and outcome of nosocomial Candida spp. Bloodstream infection in Shanghai. BMC Infect. Dis. 2014, 14, 241. [CrossRef] [PubMed]

17. Farmakiotis, D.; Kyvernitakis, A.; Tarrand, J.J.; Kontoyiannis, D.P. Early initiation of appropriate treatment is associated with increased survival in cancer patients with Candida glabrata fungaemia: A potential benefit from infectious disease consultation. Clin. Microbiol. Infect. 2015, 21, 79-86. [CrossRef] [PubMed]

18. Cowen, L.E.; Sanglard, D.; Howard, S.J.; Rogers, P.D.; Perlin, D.S. Mechanisms of antifungal drug resistance. Cold Spring Harb. Perspect. Med. 2014, 5, a019752. [CrossRef] [PubMed]

19. Goncalves, S.S.; Souza, A.C.; Chowdhary, A.; Meis, J.F.; Colombo, A.L. Epidemiology and molecular mechanisms of antifungal resistance in Candida and Aspergillus. Mycoses 2016, 4, 198-219.

20. Arendrup, M.C.; Bruun, B.; Christensen, J.J.; Fuursted, K.; Johansen, H.K.; Kjaeldgaard, P.; Knudsen, J.D.; Kristensen, L.; Moller, J.; Nielsen, L.; et al. National surveillance of fungemia in Denmark (2004 to 2009). J. Clin. Microbiol. 2011, 49, 325-334. [CrossRef] [PubMed]

21. Peman, J.; Canton, E.; Minana, J.J.; Florez, J.A.; Echeverria, J.; Ortega, D.N.; Alarcon, J.M.; Fontanals, D.; Sard, B.G.; Moreno, B.B.; et al. Changes in the epidemiology of fungaemia and fluconazole susceptibility of blood isolates during the last 10 years in spain: Results from the fungemyca study. Rev. Iberoam. Micol. 2011, 28, 91-99. [PubMed]

22. Lockhart, S.R.; Iqbal, N.; Cleveland, A.A.; Farley, M.M.; Harrison, L.H.; Bolden, C.B.; Baughman, W.; Stein, B.; Hollick, R.; Park, B.J.; et al. Species identification and antifungal susceptibility testing of Candida bloodstream isolates from population-based surveillance studies in two U.S. cities from 2008 to 2011. J. Clin. Microbiol. 2012, 50, 3435-3442. [CrossRef] [PubMed]

23. Ericsson, J.; Chryssanthou, E.; Klingspor, L.; Johansson, A.G.; Ljungman, P.; Svensson, E.; Sjolin, J. Candidaemia in Sweden: A nationwide prospective observational survey. Clin. Microbiol. Infect. 2013, 19, E218-E221. [CrossRef] [PubMed]

24. Pinhati, H.M.; Casulari, L.A.; Souza, A.C.; Siqueira, R.A.; Damasceno, C.M.; Colombo, A.L. Outbreak of candidemia caused by fluconazole resistant Candida parapsilosis strains in an intensive care unit. BMC Infect. Dis. 2016, 16, 433. [CrossRef] [PubMed]

25. Bizerra, F.C.; Jimenez-Ortigosa, C.; Souza, A.C.; Breda, G.L.; Queiroz-Telles, F.; Perlin, D.S.; Colombo, A.L. Breakthrough candidemia due to multidrug-resistant Candida glabrata during prophylaxis with a low dose of micafungin. Antimicrob. Agents Chemother. 2014, 58, 2438-2440. [CrossRef] [PubMed]

26. Vallabhaneni, S.; Cleveland, A.A.; Farley, M.M.; Harrison, L.H.; Schaffner, W.; Beldavs, Z.G.; Derado, G.; Pham, C.D.; Lockhart, S.R.; Smith, R.M. Epidemiology and risk factors for echinocandin nonsusceptible Candida glabrata bloodstream infections: Data from a large multisite population-based candidemia surveillance program, 2008-2014. Open Forum Infect. Dis. 2015, 2, ofv163. [CrossRef] [PubMed]

27. Alexander, B.D.; Johnson, M.D.; Pfeiffer, C.D.; Jimenez-Ortigosa, C.; Catania, J.; Booker, R.; Castanheira, M.; Messer, S.A.; Perlin, D.S.; Pfaller, M.A. Increasing echinocandin resistance in Candida glabrata: Clinical failure correlates with presence of $\mathrm{fks}$ mutations and elevated minimum inhibitory concentrations. Clin. Infect. Dis. 2013, 56, 1724-1732. [CrossRef] [PubMed]

28. Rodero, L.; Davel, G.; Soria, M.; Vivot, W.; Cordoba, S.; Canteros, C.E.; Saporiti, A.; Emifn. Multicenter study of fungemia due to yeasts in Argentina. Rev. Argent. Microbiol. 2005, 37, 189-195. [PubMed]

29. Cordoba, S.; Vivot, W.; Bosco-Borgeat, M.E.; Taverna, C.; Szusz, W.; Murisengo, O.; Isla, G.; Davel, G.; Red Nacional De Laboratorios De, M. Species distribution and susceptibility profile of yeasts isolated from blood cultures: Results of a multicenter active laboratory-based surveillance study in Argentina. Rev. Argent. Microbiol. 2011, 43, 176-185. [PubMed]

30. Lopez Moral, L.; Tiraboschi, I.N.; Schijman, M.; Bianchi, M.; Guelfand, L.; Cataldi, S.; integrantes de la Red de Micología de la Ciudad de Buenos Aires. Fungemia in hospitals of the city of Buenos aires, Argentina. Rev. Iberoam. Micol. 2012, 29, 144-149. [CrossRef] [PubMed]

31. Riera, F.; Medeot, M.; Sartori, L.; Bergallo, C.; Minoli, J.; Vilchez, V.; Sanchez, P.; Abiega, C.; Pincheira, C.; Correa, S.; et al. Candidemia epidemiology in Cordoba Argentina. Surveillance study of five institutions. Rev. Fac. Cien. Med. Univ. Nac. Cordoba. 2014, 71, 89-93. [PubMed] 
32. Colombo, A.L.; Nucci, M.; Salomao, R.; Branchini, M.L.; Richtmann, R.; Derossi, A.; Wey, S.B. High rate of non-albicans candidemia in brazilian tertiary care hospitals. Diagn. Microbiol. Infect. Dis. 1999, 34, 281-286. [CrossRef]

33. Costa, S.F.; Marinho, I.; Araujo, E.A.; Manrique, A.E.; Medeiros, E.A.; Levin, A.S. Nosocomial fungaemia: A 2-year prospective study. J. Hosp. Infect. 2000, 45, 69-72. [CrossRef] [PubMed]

34. Colombo, A.L.; Nakagawa, Z.; Valdetaro, F.; Branchini, M.L.; Kussano, E.J.; Nucci, M. Susceptibility profile of 200 bloodstream isolates of Candida spp. Collected from Brazilian tertiary care hospitals. Med. Mycol. 2003, 41, 235-239. [CrossRef] [PubMed]

35. Goldani, L.Z.; Mario, P.S. Candida tropicalis fungemia in a tertiary care hospital. J. Infect. 2003, 46, 155-160. [CrossRef] [PubMed]

36. Antunes, A.G.; Pasqualotto, A.C.; Diaz, M.C.; d'Azevedo, P.A.; Severo, L.C. Candidemia in a Brazilian tertiary care hospital: Species distribution and antifungal susceptibility patterns. Rev. Inst. Med. Trop. Sao Paulo 2004, 46, 239-241. [CrossRef] [PubMed]

37. Aquino, V.R.; Lunardi, L.W.; Goldani, L.Z.; Barth, A.L. Prevalence, susceptibility profile for fluconazole and risk factors for candidemia in a tertiary care hospital in Southern Brazil. Braz. J. Infect. Dis. 2005, 9, 411-418. [CrossRef] [PubMed]

38. Colombo, A.L.; Nucci, M.; Park, B.J.; Nouer, S.A.; Arthington-Skaggs, B.; da Matta, D.A.; Warnock, D.; Morgan, J.; Brazilian Network Candidemia, S. Epidemiology of candidemia in brazil: A nationwide sentinel surveillance of candidemia in eleven medical centers. J. Clin. Microbiol. 2006, 44, 2816-2823. [CrossRef] [PubMed]

39. Medrano, D.J.A.; Brilhante, R.S.N.; Cordeiro, R.A.; Rocha, M.F.G.; Rabenhorst, S.H.B.; Sidrim, J.J. Candidemia in a Brazilian hospital: The importance of Candida parapsilosis. Rev. Inst. Med. Trop. Sao Paulo 2006, 48, 4. [CrossRef]

40. Colombo, A.L.; Guimaraes, T.; Silva, L.R.; de Almeida Monfardini, L.P.; Cunha, A.K.; Rady, P.; Alves, T.; Rosas, R.C. Prospective observational study of candidemia in Sao Paulo, Brazil: Incidence rate, epidemiology, and predictors of mortality. Infect. Control. Hosp. Epidemiol. 2007, 28, 570-576. [CrossRef] [PubMed]

41. Da Matta, D.A.; de Almeida, L.P.; Machado, A.M.; Azevedo, A.C.; Kusano, E.J.; Travassos, N.F.; Salomao, R.; Colombo, A.L. Antifungal susceptibility of 1000 candida bloodstream isolates to 5 antifungal drugs: Results of a multicenter study conducted in Sao Paulo, Brazil, 1995-2003. Diagn. Microbiol. Infect. Dis. 2007, 57, 399-404. [CrossRef] [PubMed]

42. Girao, E.; Levin, A.S.; Basso, M.; Gobara, S.; Gomes, L.B.; Medeiros, E.A.; Costa, S.F. Seven-year trend analysis of nosocomial candidemia and antifungal (fluconazole and caspofungin) use in intensive care units at a Brazilian university hospital. Med. Mycol. 2008, 46, 581-588. [CrossRef] [PubMed]

43. Franca, J.C.; Ribeiro, C.E.; Queiroz-Telles, F. Candidemia in a Brazilian tertiary care hospital: Incidence, frequency of different species, risk factors and antifungal susceptibility. Rev. Soc. Bras. Med. Trop. 2008, 41, 23-28. [PubMed]

44. Motta, A.L.; Almeida, G.M.; Almeida Junior, J.N.; Burattini, M.N.; Rossi, F. Candidemia epidemiology and susceptibility profile in the largest Brazilian teaching hospital complex. Braz. J. Infect. Dis. 2010, 14, 441-448. [CrossRef]

45. Sampaio Camargo, T.Z.; Marra, A.R.; Silva, C.V.; Cardoso, M.F.; Martino, M.D.; Camargo, L.F.; Correa, L. Secular trends of candidemia in a tertiary care hospital. Am. J. Infect. Control. 2010, 38, 546-551. [CrossRef] [PubMed]

46. Bonfietti, L.X.; Szeszs, M.W.; Chang, M.R.; Martins, M.A.; Pukinskas, S.R.; Nunes, M.O.; Pereira, G.H.; Paniago, A.M.; Purisco, S.U.; Melhem, M.S. Ten-year study of species distribution and antifungal susceptibilities of candida bloodstream isolates at a Brazilian tertiary hospital. Mycopathologia 2012, 174, 389-396. [CrossRef] [PubMed]

47. Hoffmann-Santos, H.D.; Paula, C.R.; Yamamoto, A.C.; Tadano, T.; Hahn, R.C. Six-year trend analysis of nosocomial candidemia and risk factors in two intensive care hospitals in Mato Grosso, Midwest region of Brazil. Mycopathologia 2013, 176, 409-415. [CrossRef] [PubMed]

48. Moretti, M.L.; Trabasso, P.; Lyra, L.; Fagnani, R.; Resende, M.R.; de Oliveira Cardoso, L.G.; Schreiber, A.Z. Is the incidence of candidemia caused by Candida glabrata increasing in Brazil? Five-year surveillance of candida bloodstream infection in a university reference hospital in Southeast Brazil. Med. Mycol. 2013, 51, 225-230. [CrossRef] [PubMed] 
49. Santos, E.R.; Dal Forno, C.F.; Hernandez, M.G.; Kubica, T.F.; Venturini, T.P.; Chassot, F.; Santurio, J.M.; Alves, S.H. Susceptibility of Candida spp. Isolated from blood cultures as evaluated using the M27-A3 and new M27-S4 approved breakpoints. Rev. Inst. Med. Trop. Sao Paulo 2014, 56, 477-482. [CrossRef] [PubMed]

50. Da Costa, V.G.; Quesada, R.M.; Abe, A.T.; Furlaneto-Maia, L.; Furlaneto, M.C. Nosocomial bloodstream candida infections in a tertiary-care hospital in South Brazil: A 4-year survey. Mycopathologia 2014, 178, 243-250. [CrossRef] [PubMed]

51. Doi, A.M.; Pignatari, A.C.; Edmond, M.B.; Marra, A.R.; Camargo, L.F.; Siqueira, R.A.; da Mota, V.P.; Colombo, A.L. Epidemiology and microbiologic characterization of nosocomial candidemia from a brazilian national surveillance program. PLoS ONE 2016, 11, e0146909. [CrossRef] [PubMed]

52. Cortes, J.A.; Reyes, P.; Gomez, C.; Buitrago, G.; Leal, A.L.; Group, G. Fungal bloodstream infections in tertiary care hospitals in Colombia. Rev. Iberoam. Micol. 2011, 28, 74-78. [CrossRef] [PubMed]

53. Cortes, J.A.; Jaimes, J.A.; Leal, A.L. Incidence and prevalence of candidemia in critically ill patients in Colombia. Rev. Chil. Infectol. 2013, 30, 599-604. [CrossRef] [PubMed]

54. Cortes, J.A.; Reyes, P.; Gomez, C.H.; Cuervo, S.I.; Rivas, P.; Casas, C.A.; Sanchez, R. Clinical and epidemiological characteristics and risk factors for mortality in patients with candidemia in hospitals from Bogota, Colombia. Braz J. Infect. Dis. 2014, 18, 631-637. [CrossRef] [PubMed]

55. Ortiz Ruiz, G.; Osorio, J.; Valderrama, S.; Alvarez, D.; Elias Diaz, R.; Calderon, J.; Ballesteros, D.; Franco, A. Risk factors for candidemia in non-neutropenic critical patients in Colombia. Med. Intensiva 2016, 40, 139-144. [CrossRef] [PubMed]

56. Villalobos, J.M.; Castro, J.A.; Aviles, A.; Pelaez, M.C.; Somogyi, T.; Sandoval, L. Candida parapsilosis: A major cause of bloodstream infection in a tertiary care hospital in Costa Rica. Rev. Chil. Infectol. 2016, 33, 159-165. [CrossRef] [PubMed]

57. Gonzalez, G.M.; Elizondo, M.; Ayala, J. Trends in species distribution and susceptibility of bloodstream isolates of candida collected in Monterrey, Mexico, to seven antifungal agents: Results of a 3-year (2004 to 2007) surveillance study. J. Clin. Microbiol. 2008, 46, 2902-2905. [CrossRef] [PubMed]

58. Corzo-Leon, D.E.; Alvarado-Matute, T.; Colombo, A.L.; Cornejo-Juarez, P.; Cortes, J.; Echevarria, J.I.; Guzman-Blanco, M.; Macias, A.E.; Nucci, M.; Ostrosky-Zeichner, L.; et al. Surveillance of Candida spp. bloodstream infections: Epidemiological trends and risk factors of death in two Mexican tertiary care hospitals. PLoS ONE 2014, 9, e97325. [CrossRef] [PubMed]

59. Bustamante, B.; Martins, M.A.; Bonfietti, L.X.; Szeszs, M.W.; Jacobs, J.; Garcia, C.; Melhem, M.S. Species distribution and antifungal susceptibility profile of candida isolates from bloodstream infections in Lima, Peru. J. Med. Microbiol. 2014, 63, 855-860. [CrossRef] [PubMed]

60. Conde-Rosa, A.; Amador, R.; Perez-Torres, D.; Colon, E.; Sanchez-Rivera, C.; Nieves-Plaza, M.; Gonzalez-Ramos, M.; Bertran-Pasarell, J. Candidemia distribution, associated risk factors, and attributed mortality at a university-based medical center. PR Health Sci. J. 2010, 29, $26-29$.

61. Franco, M.E.D.; Reviakina, V.; Panizo, M.M.; Macero, C.; Moreno, X.; Calvo, A.; Selgrad, S.; Papatzikos, J.; Vergara, V.; Mendoza, M.J. Distribution and antifungal susceptibility of candida clinical isolations coming from six health care centers in the metropolitan area of Caracas, Venezuela (years 2003-2005). Rev. Iberoam. Micol. 2008, 25, 5.

62. Pfaller, M.A.; Jones, R.N.; Doern, G.V.; Sader, H.S.; Messer, S.A.; Houston, A.; Coffman, S.; Hollis, R.J. Bloodstream infections due to candida species: Sentry antimicrobial surveillance program in North America and Latin America, 1997-1998. Antimicrob. Agents Chemother. 2000, 44, 747-751. [CrossRef] [PubMed]

63. Pfaller, M.A.; Diekema, D.J.; Jones, R.N.; Sader, H.S.; Fluit, A.C.; Hollis, R.J.; Messer, S.A.; Group, S.P. International surveillance of bloodstream infections due to candida species: Frequency of occurrence and in vitro susceptibilities to fluconazole, ravuconazole, and voriconazole of isolates collected from 1997 through 1999 in the sentry antimicrobial surveillance program. J. Clin. Microbiol. 2001, 39, 3254-3259. [PubMed]

64. Godoy, P.; Tiraboschi, I.N.; Severo, L.C.; Bustamante, B.; Calvo, B.; Almeida, L.P.; da Matta, D.A.; Colombo, A.L. Species distribution and antifungal susceptibility profile of Candida spp. Bloodstream isolates from Latin American hospitals. Mem. Inst. Oswaldo Cruz 2003, 98, 401-405. [CrossRef] [PubMed]

65. Nishikaku, A.S.; Melo, A.S.A.; Colombo, A.L. Geographic trends in invasive candidiasis. Curr. Fungal Infect. Rep. 2010, 4, 210-218. [CrossRef] 
66. Pfaller, M.A.; Diekema, D.J. Epidemiology of invasive candidiasis: A persistent public health problem. Clin. Microbiol. Rev. 2007, 20, 133-163. [CrossRef] [PubMed]

67. Pappas, P.G.; Kauffman, C.A.; Andes, D.R.; Clancy, C.J.; Marr, K.A.; Ostrosky-Zeichner, L.; Reboli, A.C.; Schuster, M.G.; Vazquez, J.A.; Walsh, T.J.; et al. Clinical practice guideline for the management of Candidiasis: 2016 update by the infectious diseases society of America. Clin. Infect. Dis. 2016, 62, e1-e50. [CrossRef] [PubMed]

68. Colombo, A.L.; Guimaraes, T.; Camargo, L.F.; Richtmann, R.; Queiroz-Telles, F.; Salles, M.J.; Cunha, C.A.; Yasuda, M.A.; Moretti, M.L.; Nucci, M. Brazilian guidelines for the management of Candidiasis-A joint meeting report of three medical societies: Sociedade brasileira de infectologia, sociedade paulista de infectologia and sociedade brasileira de medicina tropical. Braz. J. Infect. Dis. 2013, 17, 283-312. [CrossRef] [PubMed]

69. Merseguel, K.B.; Nishikaku, A.S.; Rodrigues, A.M.; Padovan, A.C.; e Ferreira, R.C.; de Azevedo Melo, A.S.; Briones, M.R.; Colombo, A.L. Genetic diversity of medically important and emerging candida species causing invasive infection. BMC Infect. Dis. 2015, 15, 57. [CrossRef] [PubMed]

70. Van Veen, S.Q.; Claas, E.C.; Kuijper, E.J. High-throughput identification of bacteria and yeast by matrix-assisted laser desorption ionization-time of flight mass spectrometry in conventional medical microbiology laboratories. J. Clin. Microbiol. 2010, 48, 900-907. [CrossRef] [PubMed]

71. Pulcrano, G.; Iula, D.V.; Vollaro, A.; Tucci, A.; Cerullo, M.; Esposito, M.; Rossano, F.; Catania, M.R. Rapid and reliable MALDI-TOF mass spectrometry identification of candida non-albicans isolates from bloodstream infections. J. Microbiol. Methods 2013, 94, 262-266. [CrossRef] [PubMed]

72. Calvo, B.; Melo, A.S.; Perozo-Mena, A.; Hernandez, M.; Francisco, E.C.; Hagen, F.; Meis, J.F.; Colombo, A.L. First report of candida auris in America: Clinical and microbiological aspects of 18 episodes of candidemia. J. Infect. 2016, 73, 369-374. [CrossRef] [PubMed]

73. Morales-Lopez, S.E.; Parra-Giraldo, C.M.; Ceballos-Garzon, A.; Martinez, H.P.; Rodriguez, G.J.; Alvarez-Moreno, C.A.; Rodriguez, J.Y. Invasive infections with multidrug-resistant yeast Candida auris, Colombia. Emerg. Infect. Dis. 2017, 23, 162-164. [CrossRef] [PubMed]

74. Chowdhary, A.; Voss, A.; Meis, J.F. Multidrug-resistant candida auris: New kid on the block in hospital-associated infections? J. Hosp. Infect. 2016, 94, 209-212. [CrossRef] [PubMed]

75. Asmundsdottir, L.R.; Erlendsdottir, H.; Gottfredsson, M. Nationwide study of candidemia, antifungal use, and antifungal drug resistance in Iceland, 2000 to 2011. J. Clin. Microbiol. 2013, 51, 841-848. [CrossRef] [PubMed]

76. Cleveland, A.A.; Farley, M.M.; Harrison, L.H.; Stein, B.; Hollick, R.; Lockhart, S.R.; Magill, S.S.; Derado, G.; Park, B.J.; Chiller, T.M. Changes in incidence and antifungal drug resistance in candidemia: Results from population-based laboratory surveillance in Atlanta and Baltimore, 2008-2011. Clin. Infect. Dis. 2012, 55, 1352-1361. [CrossRef] [PubMed]

77. Minea, B.; Nastasa, V.; Moraru, R.F.; Kolecka, A.; Flonta, M.M.; Marincu, I.; Man, A.; Toma, F.; Lupse, M.; Doroftei, B.; et al. Species distribution and susceptibility profile to fluconazole, voriconazole and MXP-4509 of 551 clinical yeast isolates from a romanian multi-centre study. Eur J. Clin. Microbiol. Infect. Dis. 2015, 34, 367-383. [CrossRef] [PubMed]

78. Guinea, J.; Zaragoza, O.; Escribano, P.; Martin-Mazuelos, E.; Peman, J.; Sanchez-Reus, F.; on behalf of the CANDIPOP Project, GEIH-GEMICOMED (SEIMC), and REIPI. Molecular identification and antifungal susceptibility of yeast isolates causing fungemia collected in a population-based study in Spain in 2010 and 2011. Antimicrob. Agents Chemother. 2014, 58, 1529-1537. [CrossRef] [PubMed]

79. Souza, A.C.; Fuchs, B.B.; Pinhati, H.M.; Siqueira, R.A.; Hagen, F.; Meis, J.F.; Mylonakis, E.; Colombo, A.L. Candida parapsilosis resistance to fluconazole: Molecular mechanisms and in vivo impact in infected Galleria mellonella larvae. Antimicrob. Agents Chemother. 2015, 59, 6581-6587. [CrossRef] [PubMed]

80. Maubon, D.; Garnaud, C.; Calandra, T.; Sanglard, D.; Cornet, M. Resistance of Candida spp. to antifungal drugs in the ICU: Where are we now? Intensive Care Med. 2014, 40, 1241-1255. [CrossRef] [PubMed]

81. Arendrup, M.C.; Pfaller, M.A.; Danish Fungaemia Study Group. Caspofungin etest susceptibility testing of candida species: Risk of misclassification of susceptible isolates of C. glabrata and C. krusei when adopting the revised CLSI caspofungin breakpoints. Antimicrob. Agents Chemother. 2012, 56, 3965-3968. [CrossRef] [PubMed] 
82. Arendrup, M.C.; Perlin, D.S. Echinocandin resistance: An emerging clinical problem? Curr. Opin. Infect. Dis. 2014, 27, 484-492. [CrossRef] [PubMed]

83. Forastiero, A.; Garcia-Gil, V.; Rivero-Menendez, O.; Garcia-Rubio, R.; Monteiro, M.C.; Alastruey-Izquierdo, A.; Jordan, R.; Agorio, I.; Mellado, E. Rapid development of Candida krusei echinocandin resistance during caspofungin therapy. Antimicrob. Agents Chemother. 2015, 59, 6975-6982. [CrossRef] [PubMed] 